\title{
Improved Micropropagation of Stevia (Stevia rebaudianaBertoni) Plant
}

\author{
Eman F.A.bu El-Liel \\ Medicinal and Aromatic Plants Department, Hort. Res. Inst. Agric. Res. Center, Giza., Egypt \\ Abeer A. Mahmoud \\ Agricultural Botany Department, Faculty of Agriculture, Cairo University, Giza, Egypt \\ Azza M. Salama \\ Agricultural Botany Department, Faculty of Agriculture, Cairo University, Giza, Egypt \\ El-Mewafy A.E. El-Ghadban \\ Medicinal and Aromatic Plants Department, Hort. Res. Inst. Agric. Res. Center, Giza., Egypt \\ Mohamed K. Khalil \\ Agricultural Botany Department, Faculty of Agriculture, Cairo University, Giza, Egypt
}

Received: Dec. 3, 2018

Accepted: Jan.6, 2019

Published: Jan. 26, 2019

doi:10.5296/jas.v7i1.14268

URL: https://doi.org/10.5296/jas.v7i1.14268

\begin{abstract}
There is a great interest on the strategical plan in Egypt for the cultivation of a new crop used as source of natural sweeteners Stevia rebaudiana (Spanti) and (China-1) var. Stem nodal segments containing axillary buds were used as an explant and inoculated on Murashige and Skoog's (MS) medium containing 3\% (w/v) sucrose, 0.8\% (w/v) agar supplemented with various concentrations of flurprimidol (flur.), paclobutrazol (PBZ) and thidiazuron (TDZ). In Spanti var. maximum number of branches (6.52) and (6.4) were obtained in MS medium supplemented with $0.12 \mathrm{mg} / \mathrm{l}$ flur. and $0.2 \mathrm{mg} / \mathrm{l} \mathrm{TDZ}$, respectively with an average of 56.4 and 36.67 leaves per plantlet, having an average shoot length of 6.40 and $6.52 \mathrm{~cm}$, respectively. The best in vitro root induction (100\%) was achieved on MS medium with 0.16 $\mathrm{mg} / \mathrm{l}$ flur. with an average of 10.00 roots per plantlet and root length of $4.82 \mathrm{~cm}$ (Spanti var.). Furthermore, in China-1 var. (MS) medium supplemented with $0.16 \mathrm{mg} / 1$ flur. induced the best morphological characteristics. The rooted plantlets from explant planted on (MS) medium supplemented with $0.16 \mathrm{mg} / \mathrm{l}$ flur. were successfully established in soil and grown to maturity at the survival rate of $100 \%$ in the greenhouse in (Spanti) and (China-1) var. As a result of anatomy, all studied growth regulators significantly enhanced the anatomical
\end{abstract}


characters of stevia varieties leaf and stem.flur.at $0.16 \mathrm{mg} \backslash \mathrm{l}$ surpassed, for instance, midvein and lamina thickness, length and width of leaf vascular bundle as well as stem diameter, xylem and phloem thickness. Our data revealed that the numbers of protein bands in most of treatments are bigger than which in the control.

Keywords: stevia, tissue culture, morphological attribute, physiological characters, chlorophyll, electrophoresis, anatomy

\section{Abbreviations}

Flur.=Flurprimidol, PBZ.=Paclobutrazol, TDZ=Thidiazuran, Chl=Chlorophyll, $\mathrm{cv} .=$ Cultivar, Fig. $=$ Figure, F.W. $=$ Fresh Weight, $1=$ Liter, $\mathrm{mg}=$ Milligram, $\min =$ Minute, MS media $=$ Morashige and Skoog Media, $\mu \mathrm{g}=$ Microgram $\left(10^{-6} \mathrm{~g}\right),{ }^{\circ} \mathrm{C}=$ Degree Centigrade, $\%=$ Percent.

\section{Introduction}

Stevia plants (Stevia rebaudiana Bertoni) is a perennial bush of the family Asteraceae, formerly Compositae (Sapnaet al., 2008). The native occurrence of $S$. rebaudiana is between $22-24^{\circ} \mathrm{S}$ and $53-56^{\circ} \mathrm{W}$ in Paraguay and Brazil (Soejartoet al., 1983). Now, it is also cultivated in Japan, Korea, Thailand, China-1 and India. The genus contain about 200 species are native to South America and Central America (Oddone, 1997; Sapnaet al., 2008). It is herb with an extensive root system and brittle stems producing small, elliptic leaves. Plant height can reach up to $1 \mathrm{~m}$. The tiny white florets are perfect, borne in small corymbs of $2-6$ flowers. Corymbs are arranged in loose panicles (Oddone, 1997). The propagation through seeds is not adequate, leading to a very low seed germination percentage (Tawareet al., 2010). In the plant life cycle, the seed and seedling stages are key developmental stages conditioning the final yield of crops. Both are very sensitive to environmental stresses (Bewley and Black, 1994; Koornneefet al., 2002). So, poor seed germination is the major factor limiting large-scale cultivation of this plant.Propagation of steviais usually by stem cuttings, which is rooting easily but requires high labor inputs and that makes it costly (Goettemoeller and Ching, 1999).

In Egypt, there is a great interest on the strategical plan for the cultivation of a new crop used as source of natural sweeteners. In the last few years some trials for Stevia plant cultivation has been started in Egypt (Massoud, 2001).Its cultivation could be used as an alternative for the new land reclamation projects to reduce the sugar demands of the Egyptian markets and generate income for the growers (El-Zifzafi, 2003; Ibrahim et al., 2008).Wild stevia regenerates from seeds where germination is notably very poor due commonly to infertile seeds. Some of its varieties produce virtually no viable seeds due to their self-incompatibility, however stevia can be propagated by seeds, vegetative cuttings and tissue culture (Tamura et al., 1984).

Paclobutrazol ((2RS,3RS)-1-(4-chlorophenyl)-4,-4dimethyl-2-(1,2,4-trizol-1-yl)pentin-3-ol) as an antigibberreillnis effective in reducing growth of many species of nursery crops, particularly herbaceous perennials and containerized nursery crops. It is also a triazole compound that controls plant height by inhibiting production of gibberellins, the primary natural plant hormones responsible for cell elongation (Latimer and Whipker, 2007). 
Flurprimidol

((alpha-(1-methylethyl)-alpha-[4-(trifluoromethoxy)phenyl]-5-pyrimidinemethanol)) is a relatively new growth regulator, that has a similar chemical structure and mode of action to paclobutrazol, using on a wide range of ornamental crops, including very vigorous plant species. It is a nitrogen-containing heterocycle compound of the pyrimidine chemical class that inhibits enzyme catalyzing steps in GA biosynthesis pathway that involves oxidation of ent-kaurene to ent-kaurenoic acid, a GA precursor (Krug et al., 2006).

The present work was to discriminate between two cultivars of stevia;Spanti and China-1vars; as well as propagating stevia in vitro by using tissue culture and getting the developed complete plants under greenhouse conditions. Also, using flur., PBZ and TDZ to get shorter and thicker stems suitable for acclimatization. One of the main aims of Stevia rebaudiana Bertoni cultivar identification is to use its specific genetic material for breeding programmes. The genetic distance between varieties can be assessed through morphological characterization and genetic markers (Ahmad et al., 1996). The SDS-PAGE was implied to identify species of Stevia rebaudiana Bertoni which may be confused in the germplasm samples. In particular, the varieties which are confused and sometimes difficult to identify on the basis of morphological according to diagnostic techniques.

\section{Materials and Methods}

The current study was conducted in the period between 2015 to 2017. Plant tissue culture experiments were carried out in Plant Physiology Research Laboratory, Plant Physiology Section, Agric. Bot. Dept., Fac. Agric., Cairo Univ., Giza Egypt. Acclimatization experiment was carried out in the Green House of Olive Dept., Horticultural Institute, Agric. Res. Cent., Giza, Egypt.Anatomical studies were carried out in the period of 2015 to 2017, at Research Park, Fac. Agric., Cairo Univ. Giza Egypt.

\section{Plant material}

Actively growing shoots of Stavia rebaudiana cv. Spanti and China-1 were collected as source of explants from plants grown in the field at the Sugar Crops Research Institute (SCRI), Agric. Res. center (ARC), Ministry of Agriculture, Giza, Egypt.

\section{Tissue culture}

\section{Surface-sterilization}

Stem nodal segments (containing axillary buds) of about $1.5 \mathrm{~cm}$ in length were surface sterilized by soaking in $15 \%$ of Clorox ${ }^{\circledR}$ (sodium hypochlorite, $\mathrm{NaOCl} 5.25 \%$ ) concentration plus two drops of Tween 20 for 13 min. The segments were then rinsed three times in sterile distilled water under aseptic conditions.

\section{Effect of some growth regulators on multiplication:}

Murashige and Skoog medium (MS medium; Murashigeand Skoog, 1962) with vitamines free-hormone was provided with three types of growth regulators: flur. $(0.0,0.04,0.08,0.12$ and $0.16 \mathrm{mg} \Lambda), \operatorname{PBZ}(0.0,0.5,1.0,1.5$ and $2.0 \mathrm{mg} \Lambda)$ and $\mathrm{TDZ}(0.05,0.1,0.15$ and 0.2 
mg1). The explants were cultured in $400 \mathrm{ml}$ jars with polypropylene closures containing 40-45 $\mathrm{ml}$ medium of the solidified basal MS medium with the previously mentioned characters. The $\mathrm{pH}$ of the medium was adjusted to $5.8 \pm 0.01$. The medium was sterilized by autoclaving for 20 minutes at $121^{\circ} \mathrm{C}$ and $1.2 \mathrm{~kg} / \mathrm{cm}^{2}$. Each treatment consisted of 5 jars; each jar contained 4 explants. Cultures were incubated in a growth chamber at $27 \pm 1.0^{\circ} \mathrm{C}$ under $16 \mathrm{hrs}$ in light (1000 lux) followed $8 \mathrm{hrs}$ in darkness. The results from each experiment were collected after four weeks. Three sub cultures were carried out every three weeks interval. Collected data were obtained from third subculture.

\section{Effect of some growth regulators on acclimatization:}

The well-developed complete plantlets of root obtained by in vitro culture were gently washed under tap water to remove medium attached to the roots. Plantlets were soaked in fungicide solution $\left(2.0 \mathrm{~g} \mathrm{l}^{-1}\right.$ Benlate $\left.^{\circledR}\right)$ for $5 \mathrm{~min}$. Plantlets were transferred to plastic pots containing sterile soils consists of equal parts of vermiculite, peatmoss and sand (1:1:1). The plastic pots were placed in the green house in a mist tunnel with additional lighting. Data were collected after four weeks.

\section{Analysis of Chlorophyll:}

Three attributes were subjected to analyze the pigment concentration arechlorophyll-a, chlorophyll-b and carotenoids concentration (Slack, et al. 1973; Arnon, 1949; Bruinsma, 1963). samples are accurately weighted at $0.5 \mathrm{~g}$ of fresh plant leaf sample; then add 5 mlof dimethyl-sulphoxide (DMSO) to each tube. Samples were kept in the darkness for $24 \mathrm{hrs}$. The absorption was read at 663, 645 and $470 \mathrm{~nm}$ using spectrophotometer model (JENWAY spectrophotometer).

Estimation of chlorophylls concentration were calculated using method of Arnon (1949), according to following equations:

Chlorophyll a: 2.47 (A663) - 3.62 (A645)

Chlorophyll b: 25.06 (A645) - 6.5 (A663)

Carotenoids: $(1000 \mathrm{~A} 470-1.29 \mathrm{Ca}-53.78 \mathrm{Cb}) / 220$

\section{Anatomical study}

A microscopically study was carried out to investigate the anatomical structure of stevia leaf and stem represented by the $4^{\text {th }}$ internode counted from the plant tip at the age of 30 days. Specimens were killed and fixed for at least 48 hours in F.A.A. (10 $\mathrm{ml}$ formalin, $5 \mathrm{ml}$ glacial acetic acid, $50 \mathrm{ml}$ ethyl alcohol $95 \%$, and $35 \mathrm{ml}$ distilled water). Plant materials were washed in $50 \%$ ethyl alcohol and dehydrated in a normal butyl alcohol series before being embedded in paraffin wax (melting point $56^{\circ} \mathrm{C}$ ). Transverse sections, $20 \mu$ thick, were cut using a rotary microtome, double stained with crystal violet/erythrosine, cleared in xylene and mounted in Canada balsam (Nassar and El-Sahhar, 1998). The slides were microscopically examined and photomicrographed to detect histological manifestations of noticeable responses resulted from treating with TDZ, flurprimidol and PBZ. 


\section{Macrothink}

\section{Protein Electrophoresis}

\section{Leaf storage protein:}

SDS-polyacrylamide gel electrophoresis was performed in $12 \%$ acrylamide slab gels following the system of (Laemmli, 1970) to identify their protein profiles.

\section{Gel Analysis:}

Gels were photographed scanned, analyzed using Gel Doc Vilber Lourmat system (Cleaver 10X10 U.K).

\section{Isozymes electrophoresis}

Extraction of Stevia rebaudiana Bertoni leaves isozymes was used as described by Jonathan and Weeden (1990).

Native-polacrylamide gel electrophoresis (Native-PAGE) was performed in 12\% (W/V) slab gel (Davis, 1964). The gel was stained after run according to (Tankesly and Rick, 1980) for poly phenoloxidase (PPO) isozymes and Grahamet al., (1964) for peroxidase isozymes. The staining gel was incubated at $37{ }^{\circ} \mathrm{C}$ in dark for complete staining after adding the appropriate substrates and staining solutions.

\section{Gel documentation}

Gels were photographed scanned, analyzed using Gel Doc VilberLourmat system to capture the image and to calculate band intensities.

\section{Data Analysis}

The averages and standard error were computed for all data. The analysis of variance was carried out for the whole attributes using Complete Randomized Block Design (CRD) according to Gomez and Gomez (1984). Mean treatments were compared using Least Significant Difference (LSD 0.05).Five replication were used for plant tissue culture experiments were used. While only three replicates were used for acclimatization experiments.

\section{Results and Discussions}

\section{Variability and Effects the Growth Regulators of Morphological Criteria.}

\section{Morphological characters in tissue culture:}

Data in Table (1) showed the obtained results for morphological data for Spanti var. both treatments of Flur. and TDZ resulted in 100\% survival rate. While the mean average treatment of PBZ showed only 55\% survival rate. As for main shoot length, the highest value of treatment mean average of Flur. was $(4.18 \mathrm{~cm})$, followed by TDZ treatment $(2.75 \mathrm{~cm})$. While the least treatment mean value was obtained by the PBZ treatment $(1.52 \mathrm{~cm})$. These results are in agreement with Hajihashemi and Geuns (2017) who mentioned that PBZ induced shorter plants with smaller internodes while GA treatment resulted in taller plants. 
Similar data were obtained for No. of branches, mean length of branches, and leaf No. Rooting percentage, root numbers, root length and fresh weight as a result of the treatments Flur., PBZ. and TDZ.in line with Ilczuket al. (2005) who said that in Hippeastrum increase in propagation rate by Flur. And the number of bulblets was doubled by this growth retardant. As for China-1 var. in Table (2) the same trends were obtained for the previously mentioned characters. However, Spanti var. excelled China-1 var. in the morphological data characters.

The obtained results were in agreement with Mahdy et al. (2012) on Corchorus spp., Ojeda et al. (2013) on four species of Vigna Savi and Selvakumar and Kumari (2015) on cowpea. These characteristics permitted to distinguish the cultivars and construct an identification key that could be useful for agronomic or floricultural purposes. These attribute which is considered as a quantitative trait that was controlled by polygenes and influenced by environmental conditions. These results confirmed that the genetic variability for important criteria was highly significant and subsequently they permit to improve of it.

Table 1. Average of data for morphological characteristics under study of steviarebaudianaplant var.Spanti at third subculture

\begin{tabular}{|c|c|c|c|c|c|c|c|c|c|c|c|}
\hline Treatments & $\begin{array}{c}\text { Conc. } \\
\text { mg1 }\end{array}$ & $\begin{array}{c}\text { Survival } \\
\%\end{array}$ & $\begin{array}{c}\text { Length } \\
\text { of } \\
\text { main } \\
\text { shoot } \\
\text { (cm) }\end{array}$ & $\begin{array}{c}\text { Number } \\
\text { of } \\
\text { branches }\end{array}$ & $\begin{array}{c}\text { Mean } \\
\text { Length } \\
\text { of } \\
\text { branches } \\
\text { (cm) } \\
\end{array}$ & $\begin{array}{c}\text { Leaf } \\
\text { numbers }\end{array}$ & $\begin{array}{c}\text { Rooting } \\
\%\end{array}$ & $\begin{array}{c}\text { Root } \\
\text { numbers }\end{array}$ & $\begin{array}{c}\text { Root } \\
\text { length } \\
\text { (cm) }\end{array}$ & $\begin{array}{l}\text { F. w. } \\
(\mathrm{g})\end{array}$ & Callus \\
\hline \multirow{5}{*}{ Flur. } & Cont. & 100.00 & 4.80 & 4.00 & 4.40 & 41.40 & 93.60 & 4.80 & 6.64 & 0.60 & - \\
\hline & 0.04 & 100.00 & 3.62 & 4.00 & 4.12 & 44.20 & 93.60 & 4.80 & 4.64 & 0.78 & - \\
\hline & 0.08 & 100.00 & 3.14 & 4.00 & 5.02 & 42.20 & 100.00 & 7.60 & 4.38 & 1.59 & - \\
\hline & 0.12 & 100.00 & 4.18 & 6.40 & 4.44 & 56.40 & 93.60 & 6.80 & 3.98 & 1.72 & - \\
\hline & 0.16 & 100.00 & 5.18 & 4.80 & 4.56 & 47.20 & 100.00 & 10.00 & 4.82 & 1.14 & - \\
\hline \multicolumn{2}{|l|}{ Mean } & 100.00 & 4.18 & 4.64 & 4.51 & 46.28 & 96.16 & 6.8 & 4.89 & 1.17 & \\
\hline \multirow{5}{*}{ PBZ } & Cont. & 100.00 & 2.60 & 2.20 & 3.10 & 24.40 & 50.00 & 6.20 & 4.06 & 0.15 & - \\
\hline & 0.5 & 45.00 & 1.58 & 0.40 & 0.16 & 6.00 & 5.00 & 0.20 & - & 0.12 & - \\
\hline & 1.0 & 50.00 & 1.68 & - & - & 4.20 & - & - & - & 0.14 & - \\
\hline & 1.5 & 45.00 & 1.75 & 0.80 & 0.37 & 5.00 & - & - & - & 0.17 & - \\
\hline & 2.0 & 35.00 & 1.51 & 0.40 & 0.28 & 3.80 & - & - & - & 0.20 & - \\
\hline \multicolumn{2}{|l|}{ Mean } & 55.00 & 1.82 & 0.95 & 0.98 & 8.68 & 27.5 & 3.2 & 4.06 & 0.17 & \\
\hline \multirow{5}{*}{ TDZ } & Cont. & 100.00 & 1.80 & 1.80 & 2.70 & 20.20 & 55.00 & 1.60 & 1.58 & 0.08 & - \\
\hline & 0.05 & 100.00 & 2.96 & 4.76 & 4.56 & 39.44 & 30.00 & 0.40 & 2.90 & 0.49 & ++ \\
\hline & 0.1 & 100.00 & 2.46 & 4.48 & 2.68 & 39.04 & 30.00 & 0.63 & 0.78 & 0.38 & ++ \\
\hline & 0.15 & 100.00 & 3.30 & 4.90 & 2.00 & 23.92 & 16.66 & 0.45 & 0.38 & 0.39 & +++ \\
\hline & 0.2 & 100.00 & 3.22 & 6.52 & 1.50 & 36.66 & - & - & - & 0.73 & +++++ \\
\hline \multicolumn{2}{|l|}{ Mean } & 100.00 & 2.75 & 4.49 & 2.69 & 31.85 & 32.93 & 0.77 & 1.41 & 0.41 & \\
\hline \multirow{2}{*}{\multicolumn{2}{|c|}{$\begin{array}{l}\text { L.S.D (0.05) } \\
\text { L.S.D (0.01) }\end{array}$}} & 20.62 & 1.18 & 2.05 & 1.67 & 14.94 & 28.56 & 3.19 & 2.13 & 0.45 & \\
\hline & & 27.45 & 1.57 & 2.73 & 2.21 & 19.89 & 38.01 & 4.25 & 2.84 & 0.60 & \\
\hline
\end{tabular}

F.W. = Fresh weight, Flur. $=$ Flurprimidol, PBZ $=$ Paclobutrazol, TDZ $=$ Thidiazuran . 
Table 2. Morphological characteristics under study of steviarebaudianaplant var.China-1 at third subculture

\begin{tabular}{|c|c|c|c|c|c|c|c|c|c|c|c|}
\hline treatments & $\begin{array}{c}\text { Conc. } \\
\text { mg1 }\end{array}$ & $\begin{array}{c}\text { Survival } \\
\%\end{array}$ & $\begin{array}{c}\text { Length of } \\
\text { main } \\
\text { shoot } \\
(\mathrm{cm})\end{array}$ & $\begin{array}{c}\text { Number } \\
\text { of } \\
\text { branches }\end{array}$ & $\begin{array}{l}\text { MeanLength } \\
\text { of } \\
\text { branches }(\mathrm{cm})\end{array}$ & $\begin{array}{c}\text { Leaf } \\
\text { numbers }\end{array}$ & $\begin{array}{c}\text { Rooting } \\
\%\end{array}$ & $\begin{array}{c}\text { Root } \\
\text { numbers }\end{array}$ & Rootlength $(\mathrm{cm})$ & $\begin{array}{l}\text { F. } \\
\text { w. } \\
\text { (g) }\end{array}$ & Callus \\
\hline \multirow{4}{*}{ Flur. } & 0.04 & 100.00 & 4.68 & 4.00 & 3.40 & 26.20 & 91.60 & 4.20 & 3.90 & 0.35 & - \\
\hline & 0.08 & 100.00 & 5.14 & 4.00 & 3.70 & 25.00 & 100.00 & 4.00 & 4.32 & 0.65 & - \\
\hline & 0.12 & 100.00 & 5.14 & 4.00 & 3.70 & 25.00 & 100.00 & 4.00 & 4.32 & 0.65 & - \\
\hline & 0.16 & 100.00 & 5.28 & 4.20 & 4.18 & 29.00 & 100.00 & 7.60 & 5.80 & 1.04 & - \\
\hline \multicolumn{2}{|c|}{ Mean } & 100.00 & 4.78 & 3.64 & 3.47 & 23.32 & 90.76 & 4.36 & 4.49 & 0.57 & \\
\hline \multirow{5}{*}{ PBZ } & Cont. & 100.00 & 4.00 & 0.80 & 2.46 & 11.20 & 55.00 & 1.60 & 2.54 & 0.19 & - \\
\hline & 0.5 & 65.00 & 1.84 & 0.40 & 0.48 & 10.40 & 25.00 & 0.60 & 0.60 & 0.21 & - \\
\hline & 1.0 & 50.00 & 1.02 & 0.40 & 0.20 & 7.80 & - & - & - & 0.12 & - \\
\hline & 1.5 & 5.00 & 0.16 & - & - & 0.40 & - & - & - & 0.20 & - \\
\hline & 2.0 & - & - & - & - & - & - & - & - & - & - \\
\hline \multicolumn{2}{|c|}{ Mean } & 55.00 & 1.76 & 0.53 & 1.05 & 7.45 & 40 & 1.1 & 1.57 & 0.18 & \\
\hline \multirow{4}{*}{ TDZ } & Cont. & 100.00 & 3.60 & 1.80 & 4.38 & 15.20 & 85.00 & 3.00 & 1.72 & 0.11 & - \\
\hline & 0.1 & 100.00 & 2.88 & 3.72 & 5.10 & 28.00 & 58.32 & 1.18 & 1.80 & 0.45 & +++ \\
\hline & 0.15 & 100.00 & 3.94 & 3.80 & 2.32 & 25.74 & 30.00 & 0.64 & 0.83 & 0.23 & +++ \\
\hline & 0.2 & 95.00 & 2.34 & 7.12 & 2.30 & 28.70 & 20.00 & 0.35 & 0.70 & 1.04 & ++++ \\
\hline \multicolumn{2}{|c|}{ Mean } & 99.00 & 3.32 & 3.84 & 3.75 & 23.73 & 55.67 & 1.34 & 1.43 & 0.42 & \\
\hline \multicolumn{2}{|c|}{ L.S.D (0.05) } & 8.80 & 1.13 & 0.81 & 0.82 & 5.75 & 21.77 & 1.36 & 1.31 & 0.38 & \\
\hline \multicolumn{2}{|c|}{ L.S.D (0.01) } & 11.71 & 1.51 & 1.62 & 1.09 & 7.65 & 28.97 & 1.81 & 1.75 & 0.50 & \\
\hline
\end{tabular}

F.W. $=$ Fresh weight, Flur. $=$ Flurprimidol, PBZ $=$ Paclobutrazol, TDZ $=$ Thidiazuran.

Effect of some growth regulators on acclimatization survival percentage 30 days after transplanting:

Data in Table (3) showed that the survival percentage of resulted plants. Spanti var. excelled China-1 var. in survival percentage with the significant values of 66.89 and $50.99 \%$, respectively.Treatments means ofFlur., TDZ and PBZ showed a descending order of the survival percentage values of 83.08, 66.04 and 51.56\%, respectively in Spanti var. Similar trend was obtained for China-1 var. According to Kozak (2006) noted that many sources the growth retardants increase the ability of plants to overcome acclimatization phase.

In general Flur. treatment produced better plantlets as compared to PBZtreatment. While TDZ treatment produced an intermediate plantlets. Plantlets treated with Flur. produced successful acclimatized plants, specially the concentration of $0.16 \mathrm{mg} / \mathrm{l}$.

Table 3. Changes of acclimatization survival percentage of stevia plant

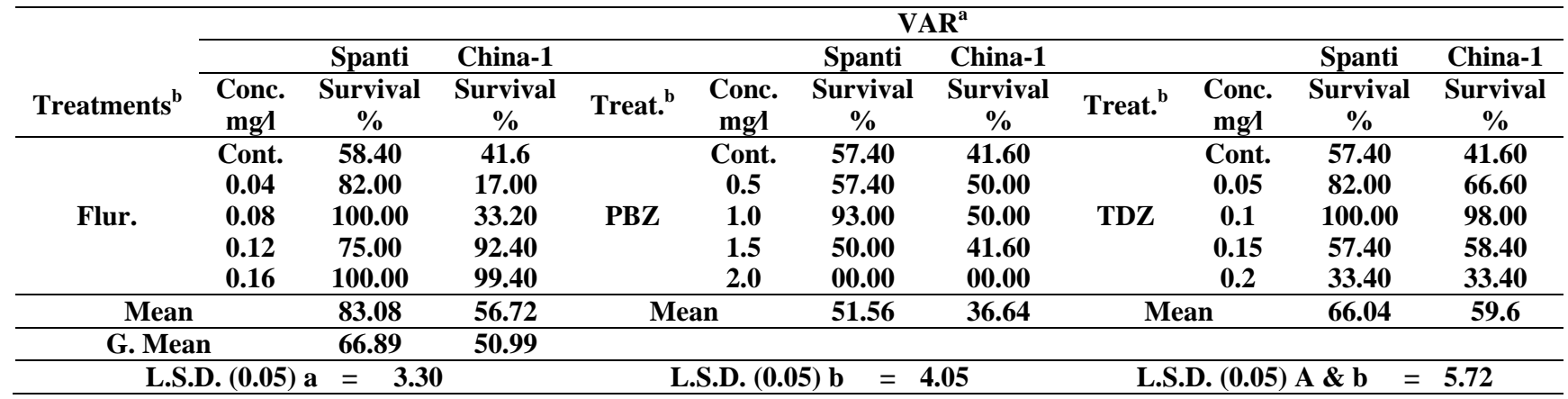

Treat. $=$ Treatments 


\section{Effect of some growth regulators on stevia chlorophylls}

As for chlorophyll (a) and chlorophyll (b) concentration generally was higher in var. Spanti than var. China-1. The same data were obtained for carotenoids i.e. higher concentration was observed in var. Spanti as compared to var. China-1 (Figs. 1 and 2) While chlorophyll (b) in both vars. showed no difference between the two vars. (Figs. 1 and 2).

Flurprimidol treatments tended to produce more chlorophyll concentration in var. Spanti as compared to the China-1 var. (Figs. 1 and 2). The same trend was obtained applies to carotenoids in var. Spanti as compared to China-1 var. However, little differences in chlorophyll (b) between the two species as a result of Flur. treatments were noticed.

Slight increase in chlorophyll (a) and chlorophyll (b) and carotenoids in Spanti var. were noticed as compared to China-1 var. as a result of the treatment with PBZ (Figs. 1 and 2).

Treatment with TDZ resulted in an increase in chlorophyll (a) concentration in Spanti var. as compared to China-1 var. However, no noticeable differences were obtained from chlorophyll (b) and Carotenoides concentration in both vars. when treated with TDZ.

From (Figs. 1 and 2), it can be concluded in general that treatment of both Flur. and TDZ produced more greener plantlets in both vars. (due to increase in chlorophylls concentration) while yellowish plantlets were produced from the treatment with PBZ in both vars. as compared to Flur. and TDZ treatments. Salachna and Zawadzińska (2013) found the relative chlorophyll content in the leaves of the plants treated with the retardant was significantly higher. 

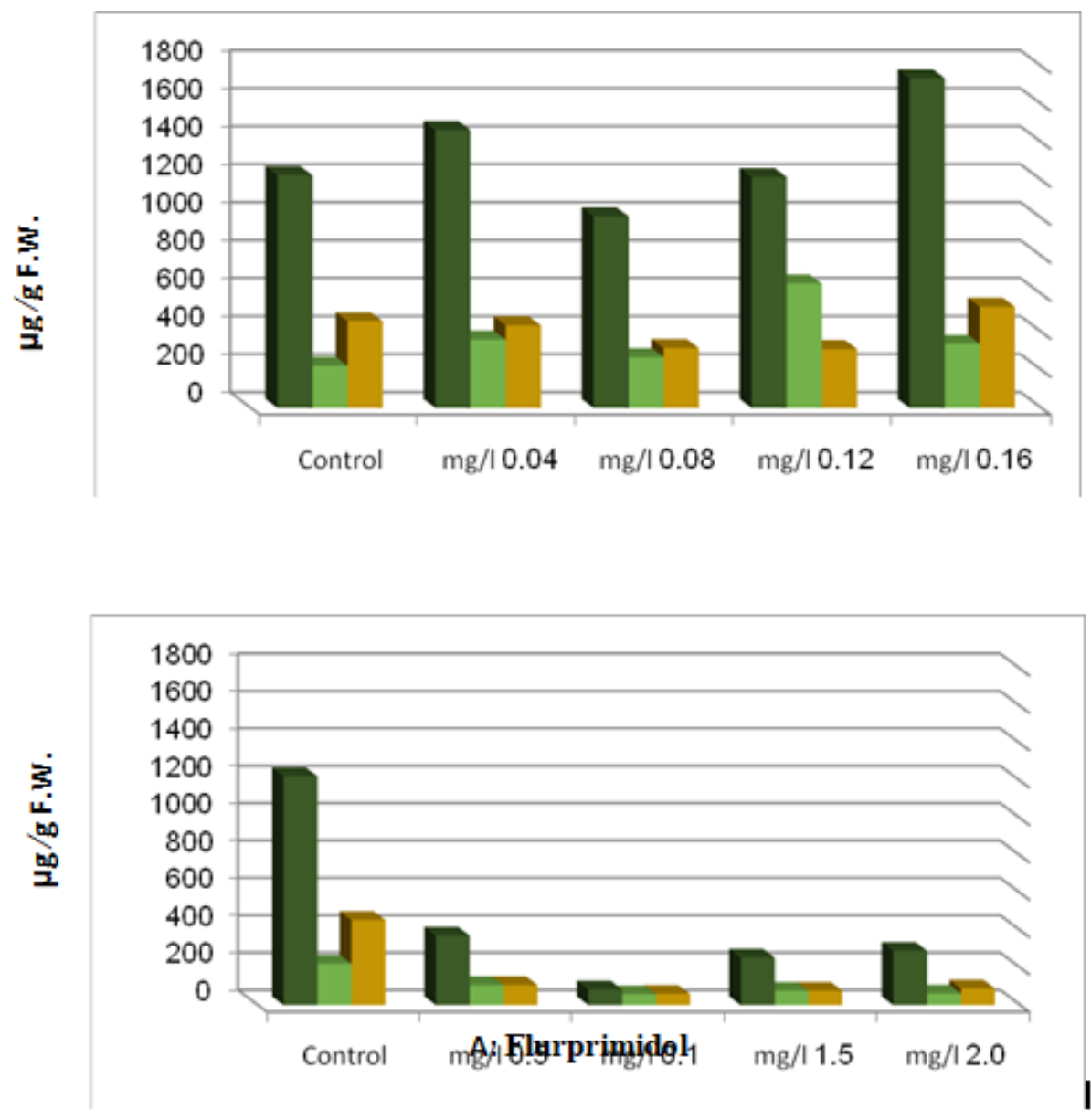

prophyll (a)

1400

1000

rophyll (b)

tenoids

B: Paclobutrazol

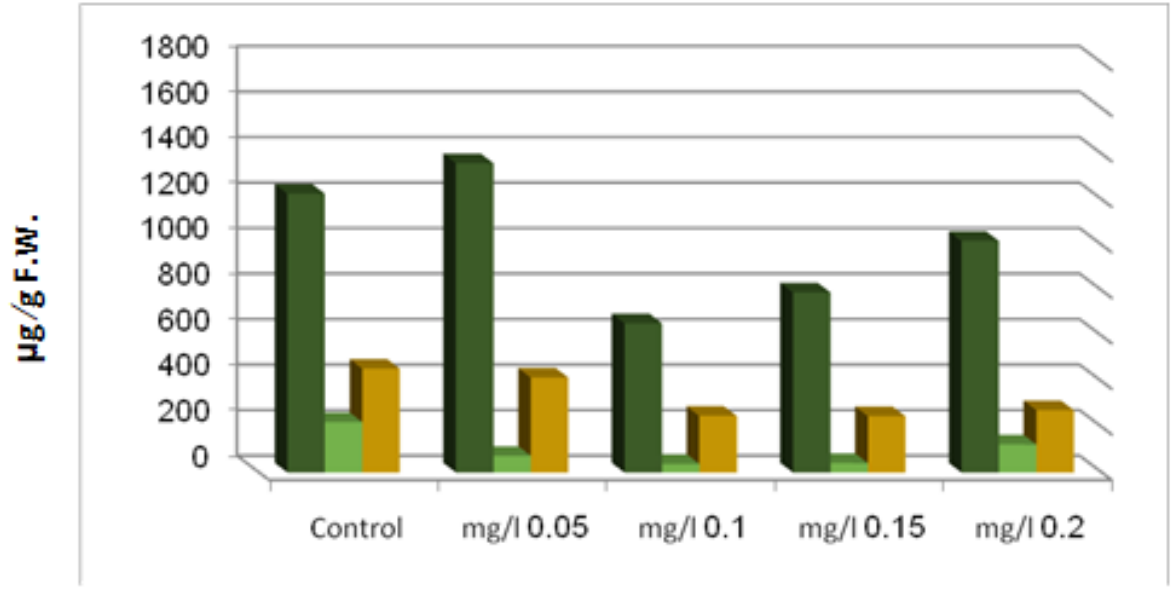

C: Thidiazuran

Fig.1. Chlorophylls (A\&b) and carotenoids ( $\mu \mathrm{g} \backslash \mathrm{g}$ F.W.) in steviarebaudianavarSpanti at the third subcultur 


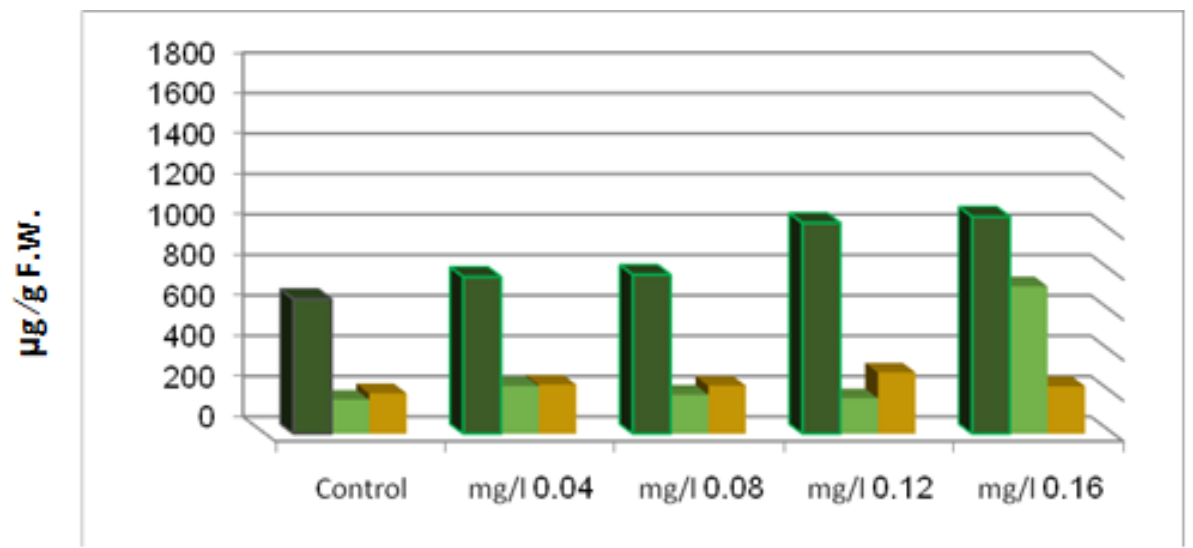

A: Flurprimidol
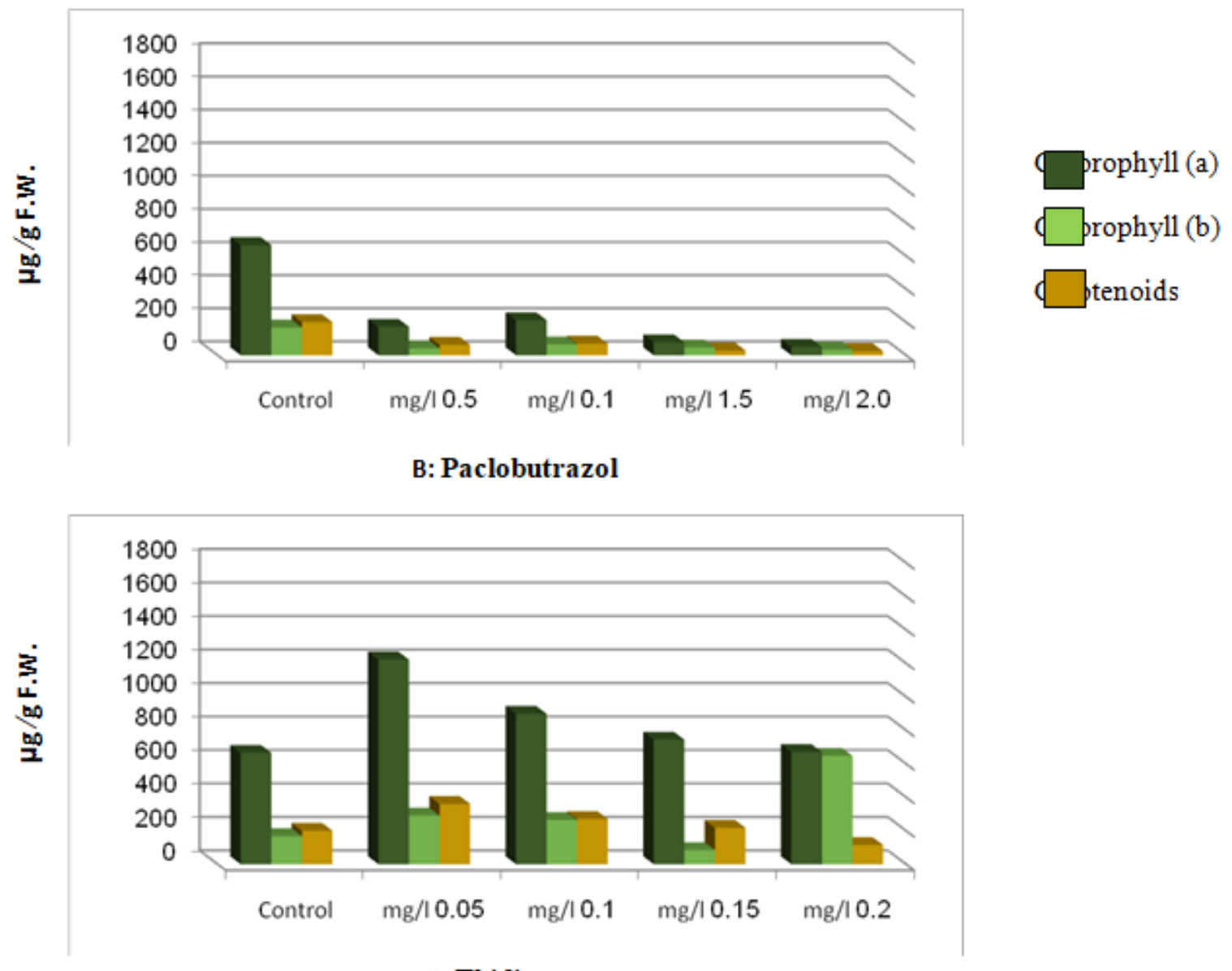

C: Thidiazuran

Fig.2. Chlorophylls (A\&b) and carotenoids ( $\mu \mathrm{g} \backslash \mathrm{g}$ F.W.) in steviarebaudianavarChina-1 at the third subculture

\section{Anatomical studies}

\section{The Leaf:}

The obtained results indicated that there were positive effects in all investigated leaves 
parameters as a result of treating with flur., TDZ and PBZ.

It is recognized from Table (4) and Fig. (3) that flur. at 0.16 resulted in thicker leaves and this impact was attributed to the increased thickness of both midvein and lamina of the two stevia cultivars by 60.8 and $42.1 \%$ for Spanti, and 67.1 and $53.0 \%$ for China-1 more than control, respectively. It is clear that the increase in lamina thickness was accompanied by increments in thickness of palisade and spongy tissues by 49.1 and $68.4 \%$ for Spanti and 60.0 and $76.1 \%$ for China- 1 over the control, respectively. Likewise, the main vascular bundle of the midvein was increased in size in Spanti and this mainly is due to the increase in length by $29.2 \%$ and in width by $40 \%$ more than control. Also, an increase was recorded in length and width of main vascular bundle of China- 1 by 51.2 and $44.8 \%$, respectively.

A

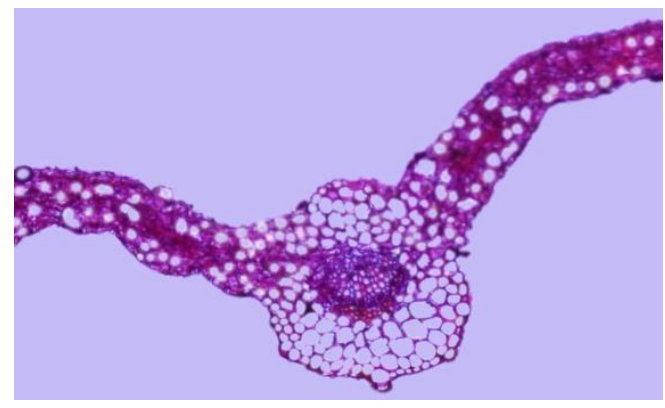

B

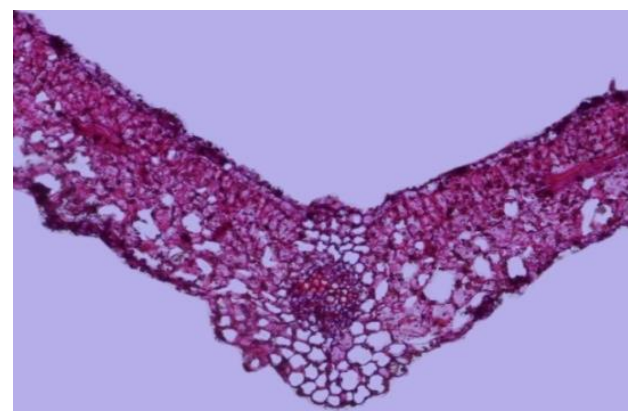

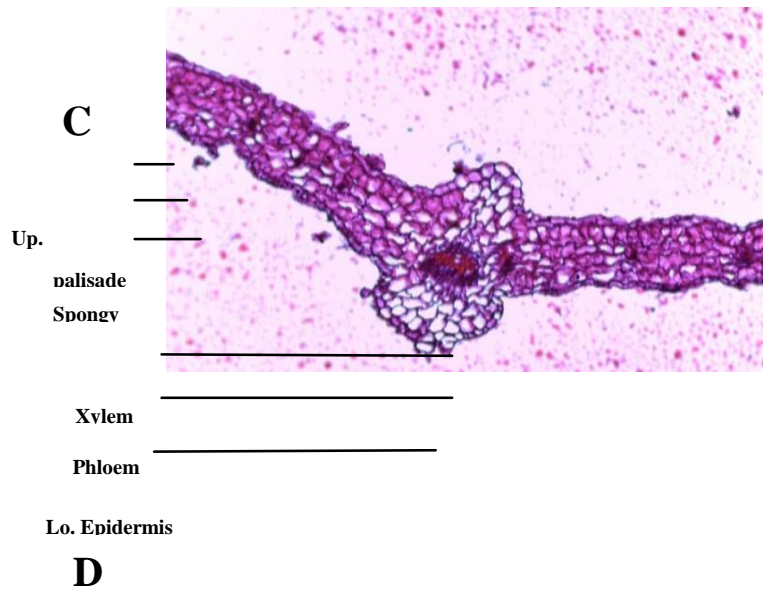

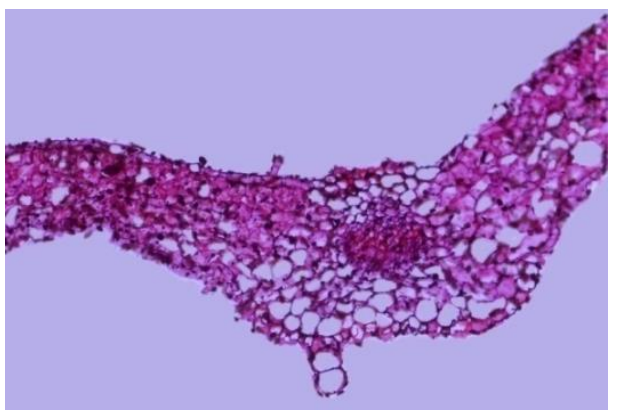

Fig. 3. Transverse sections through the blade of the $4^{\text {th }}$ leaf of two stevia cultivars (X 40). ASpanti control, B- Spanti treated with Flur. at concentration 0.16, C- China-1 control, and DChina-1 treated with Flur. at 0.16

The obtained data are in agreement with the studies found that PBZ reduces cell elongation and retards plant growth (Ahmad Nazarudin et al. 2012; Fletcher et al. 2000; Francescangeli et al. 2007; Mansuroglu et al. 2009; Rademacher 2000). AccordingtoTekalignet al. (2005) concluded that the leaves of Solanum tuberosum treated with PBZ showed elongated and thicker epidermal as well as the Palisade and spongy mesophyll cells. In addition, Jaleelet al. (2009) also found that PBZ increased leaf thickness in Catharanthu sroseus by increasing the 


\section{MInstitute ${ }_{\text {Mink }}^{\text {Macrothink }}$}

length of the mesophyll layers. palisade parenchyma thickness in the control tree was increased by $2.44 \%$, while PBZ significantly increased by $33.83 \%$. This finding was in accordance with the report of Gaoet al. (2011) which indicated that PBZ increased leaf thickness. Increased size of vascular bundles, epidermal, mesophyll and bundle sheath cells were amongst the responses in plants due to PBZ treatment (Ahmad Nazarudinet al. 2007; Gopiet al. 2008; Jenks et al. 2001; Sebastian et al. 2002; Yeshitelaet al. 2004).

The stem:

As it is clear from data in Table (5) and Fig. (4) indicated that flur. at 0.16 increased the diameter of the main stem in Spanti and China-1 vars. by 32.3 and $34.6 \%$, respectively more than control. The increase in thickness of cortex, phloem, xylem tissue and parenchymatous area of the pith in Spanti were 73.6, 42.5, 27.1 and 31.7\% more than those of the control, respectively. While in China-1 were $54.7,50.8,18.7$ and $34.1 \%$ in the same order. In this concern, Yeshitela et al. (2004), studied stem cross sections and found that xylem thickness decreased as a response to these treatments. Paclobutrazol in Mangifera indica. Also, Ahmad Nazarudin et al. (2007), showed that xylem thickness decreased as a response to PBZ treatments in $S$. campanulatum. Existence of PBZ also affected the anatomical structure in the stem of $X$. chrysanthus by reducing the xylem thickness. A similar effect of PBZ on xylem thickness was also reported in S. campanulatum Ahmad Nazarudinet al. (2007), L. styraciflua and A. glutinosa Baiet al.(2004).

A

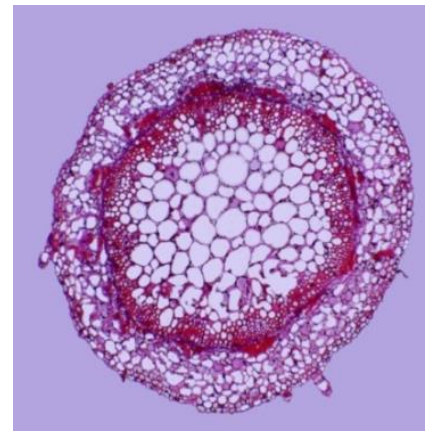

B

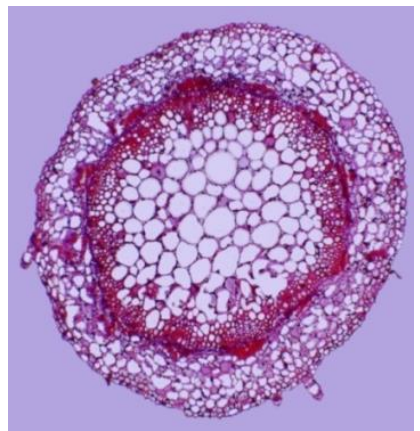

C

Epidermis

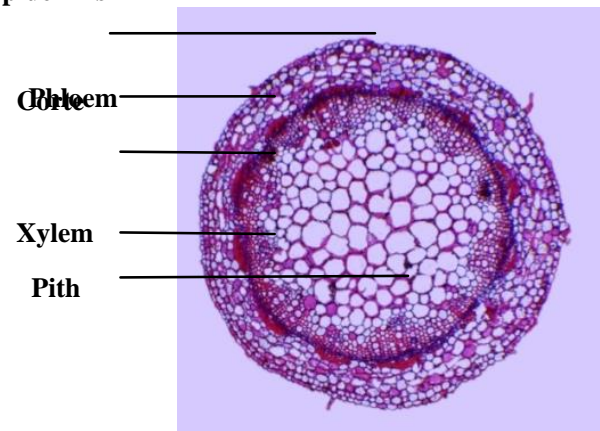

D

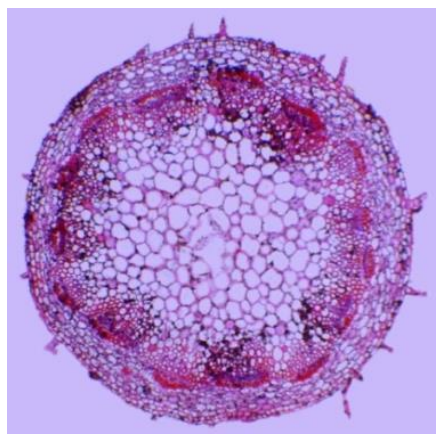

Fig. 4. Transverse sections through median portion of the main stem of two stevia cultivars (X 40). A- Spanti control, B- Spanti treated with flur. at 0.16, C- China-1 control, and DChina-1 treated with flur. at 0.16 


\section{Ml Macrothink}

Journal of Agricultural Studies

ISSN 2166-0379

2019, Vol. 7, No. 1

Table 4. Microscopical measurements $(\mu)$ and counts of certain histological features in transverse sections through the stem of stevia plant treated with Flurprimidol, Thidiazuron and Paclobutrazol at different concentrations during 2016-2017

\begin{tabular}{|c|c|c|c|c|c|c|c|c|c|c|c|c|c|c|}
\hline \multirow{2}{*}{$\begin{array}{l}\text { Histological } \\
\text { characters } \\
\text { transverse } \\
\text { sections }(\mu)\end{array}$} & \multicolumn{7}{|c|}{ Stevia cv. Spanti } & \multicolumn{7}{|c|}{ Stevia cv. China-1 } \\
\hline & Control & $\begin{array}{c}\text { Flur. } \\
\text { at } \\
0.16\end{array}$ & control & $\begin{array}{c}\text { TDZ } \\
\text { at } \\
0.2\end{array}$ & control & $\begin{array}{c}\text { PBZ } \\
\text { at } \\
0.1\end{array}$ & control & Control & $\begin{array}{c}\text { Flur. } \\
\text { at } \\
0.16\end{array}$ & control & $\begin{array}{c}\text { TDZ } \\
\text { at } \\
0.2\end{array}$ & control & $\begin{array}{c}\text { PBZ } \\
\text { at } \\
\text { 0.1 }\end{array}$ & control \\
\hline $\begin{array}{l}\text { Average } \\
\text { stem } \\
\text { diameter }\end{array}$ & 1625 & 2150 & 32.3 & 1995 & 22.7 & 1777 & 9.3 & 1756 & 2365 & 34.6 & 2070 & 17.8 & 1845 & 5.0 \\
\hline $\begin{array}{l}\text { Average } \\
\text { cortex } \\
\text { thickness } \\
\text { number of }\end{array}$ & 95 & 165 & 73.6 & 144 & 51.5 & 125 & 31.5 & 115 & 178 & 54.7 & 155 & 34.7 & 137 & 19.1 \\
\hline $\begin{array}{l}\text { cortex } \\
\text { parenchyma } \\
\text { rows }\end{array}$ & 5 & 8 & 60 & 7 & 40 & 6 & 20 & 6 & 8 & 33.3 & 7 & 16.6 & 6 & 0.0 \\
\hline $\begin{array}{l}\text { Phloem } \\
\text { tissue } \\
\text { thickness }\end{array}$ & 47 & 67 & 42.5 & 60 & 27.6 & 55 & 17.0 & 57 & 86 & 50.8 & 78 & 36.8 & 66 & 15.7 \\
\hline $\begin{array}{l}\text { Xylem } \\
\text { tissue } \\
\text { thickness }\end{array}$ & 140 & 178 & 27.1 & 166 & 18.5 & 157 & 12.1 & 155 & 184 & 18.7 & 175 & 12.9 & 167 & 7.7 \\
\hline $\begin{array}{ll}\text { No of } \\
\text { vascular } \\
\text { bundles }\end{array}$ & 12 & 17 & 41.6 & 15 & 25 & 14 & 16.6 & 12 & 18 & 50 & 15 & 25 & 14 & 16.6 \\
\hline $\begin{array}{l}\text { pith } \\
\text { diameter }\end{array}$ & 1015 & 1337 & 31.7 & 1235 & 21.6 & 1150 & 13.3 & 1111 & 1490 & 34.1 & 1370 & 23.3 & 1255 & 12.9 \\
\hline
\end{tabular}

Table 5. Microscopical measurements $(\mu)$ and counts of certain histological features in transverse sections through the leaf of stevia plant treated with Flurprimidol, Thidiazuron and Paclobutrazol at different concentrations during 2016-2017

\begin{tabular}{|c|c|c|c|c|c|c|c|c|c|c|c|c|c|c|}
\hline \multirow{2}{*}{$\begin{array}{l}\text { Histological } \\
\text { characters } \\
\text { transverse } \\
\text { sections }(\mu)\end{array}$} & \multicolumn{7}{|c|}{ Stevia cv. Spanti } & \multicolumn{7}{|c|}{ Stevia cv. China-1 } \\
\hline & Control & $\begin{array}{c}\text { Flur. } \\
\text { at } \\
0.16\end{array}$ & control & $\begin{array}{c}\text { TDZ } \\
\text { at } \\
0.2\end{array}$ & control & $\begin{array}{c}\text { PBZ. } \\
\text { at } \\
0.1\end{array}$ & control & Control & $\begin{array}{c}\text { Flur. } \\
\text { at } \\
0.16\end{array}$ & control & $\begin{array}{c}\text { TDZ } \\
\text { at } \\
0.2\end{array}$ & control & $\begin{array}{c}\text { PBZ. } \\
\text { at } \\
0.1\end{array}$ & control \\
\hline $\begin{array}{l}\text { thickness } \\
\text { of midvein }\end{array}$ & 345 & 555 & 60.8 & 537 & 55.6 & 426 & 23.4 & 320 & 535 & 67.1 & 525 & 64.0 & 412 & 28.7 \\
\hline $\begin{array}{l}\text { thickness of } \\
\text { lamina } \\
\text { Thickness }\end{array}$ & 190 & 270 & 42.1 & 252 & 32.6 & 232 & 22.1 & 166 & 254 & $\mathbf{5 3 . 0}$ & 240 & 44.5 & 216 & 30.1 \\
\hline $\begin{array}{l}\text { of palisade } \\
\text { tissue } \\
\text { Thickness }\end{array}$ & 57 & 85 & 49.1 & 70 & 22.8 & 62 & 8.7 & 50 & 80 & 60.0 & 65 & 30.0 & 55 & 10.0 \\
\hline $\begin{array}{l}\text { of spongy } \\
\text { tissue }\end{array}$ & 95 & 160 & 68.4 & 140 & 47.3 & 125 & 31.5 & 82 & 145 & 76.1 & 135 & 64.6 & 115 & 40.2 \\
\hline - Length & 147 & 190 & 29.2 & 180 & 22.4 & 166 & 12.9 & 117 & 177 & 51.2 & 160 & 36.7 & 148 & 26.4 \\
\hline & 175 & 245 & 40 & 225 & 28.5 & 193 & 10.2 & 145 & 210 & 44.8 & 195 & 34.4 & 173 & 19.3 \\
\hline
\end{tabular}

\section{SDS-Protein electrophoresis in leaves:}

The electrophoretic banding patterns of proteins extracted from leaves of different treatments of stevia cultivars (Spanti and China-1) and control are shown in Figs. (5) and (6), respectively. Their densitometric analyses are illustrated. the presence and absence of bands were assessed. The results SDS-PAGE profile of leaves revealed a total number of 8 bands with molecular weights (MW) ranging from (15.6 to $319.2 \mathrm{KDa}$ ) in cultivar Spanti while, a total number in cultivar China-1 were 4 bands with molecular weights (MW) ranging from (16.6 to $25.6 \mathrm{KDa}$ ). Analysis of data of cultivar Spanti didn't show any common band while, 


\section{Macrothink}

Journal of Agricultural Studies

ISSN 2166-0379 2019, Vol. 7, No. 1

there were four unique bands and four polymorphic bands with $100 \%$ polymorphism. The unique bands appeared at $319.2 \mathrm{KDa}$ by $0.2 \mathrm{mg} / \mathrm{l} \mathrm{TDZ}, 297.9 \mathrm{KDa}$ by $0.1 \mathrm{mg} / \mathrm{l} \mathrm{TDZ}, 26.7$ $\mathrm{KDa}$ by $0.04 \mathrm{mg} / \mathrm{l}$ flur. and $17.7 \mathrm{kDa}$ by $0.04 \mathrm{mg} / \mathrm{l} \mathrm{flur}$. All the treatment leads to present one band $(24.2 \mathrm{KDa})$ which absence in the control. On the other hand, analysis of data of cultivar China- 1 showed one common band at $25.6 \mathrm{kDa}$ while, there was one unique band at $18.7 \mathrm{kDa}$ by $(0.15 \mathrm{mg} / \mathrm{l} \mathrm{TDZ})$ and the remaining two bands were polymorphic bands with $75 \%$ polymorphism.

Our data revealed that the number of protein bands in most of treatments are bigger than which in the control that explain why most of vegetative diameters in the treatments are better than in the control such as the length and number of branches, rooting, number of root and fresh weight. The protein bands which present in the treatments and absent in control might be responsible of total chlorophyll a, chlorophyll $b$ and total carotenoid as expressions of hormone affects. Thidiazur on treatments induced the most of unique bands that explain the greatest number of branches and the highest percentage of callus which produced by using TDZ.

This indicated that treatments were successful in inducing further characterized for morphological and chemical composition traits.

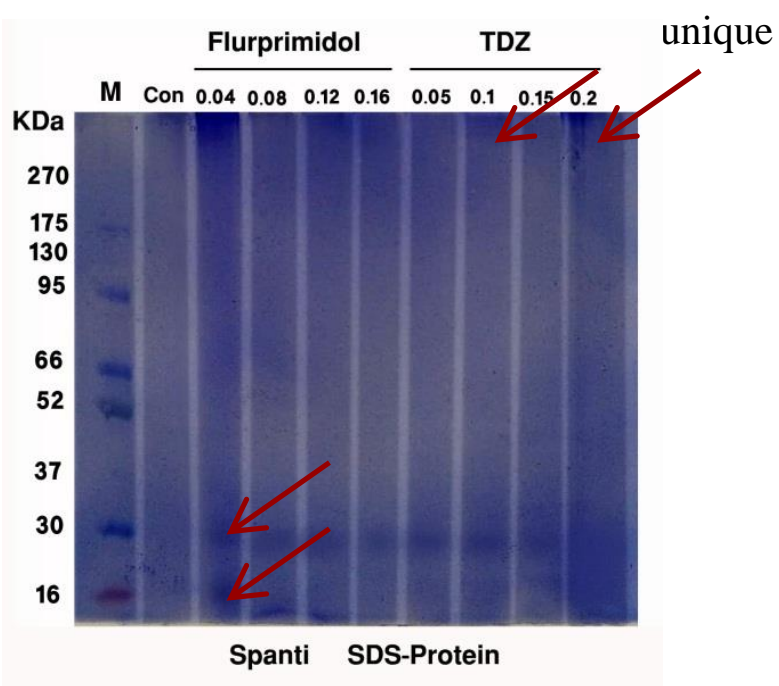

Fig. 5. SDS-protein banding patterns of leaf proteins for stevia cultivar (Spanti) as affected flurprimidol and thidiazuron(mg/l.) as compared with control(con) 


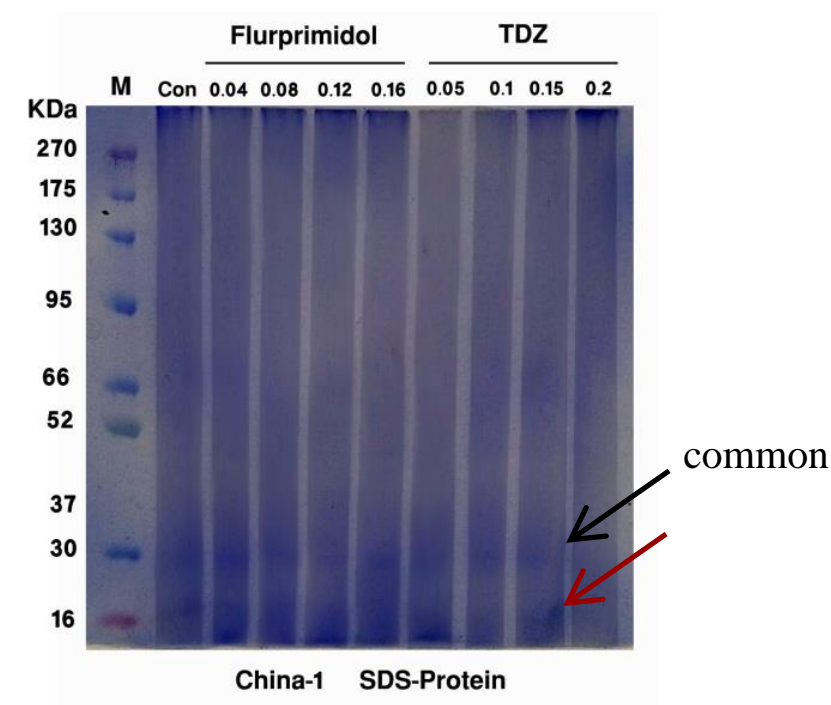

Fig. 6. SDS-protein banding patterns of leaf proteins for stevia cultivar (China-1) as affected flurprimidol and thidiazuron(mg/l.) as compared with control(con)

\section{Isozyme electrophoresis:}

Figs. (7 and 8) represent peroxidase electrophoresis banding patterns among examined leaves of different treatments of stevia cultivars (Spanti and China-1) and control, there were some differences in density of band compared with the control. Data presented in Fig. (7) explain that, in Spanti cultivar the total number of ten peroxidase bands were present in $0.2 \mathrm{mg} / \mathrm{l} \mathrm{TDZ}$ treatment while, (Px9 and Px10) were absentin 0.05mg/l,each of (Px4, Px5,Px6,Px7 and Px8) were present in all treatments and they could be considered as common bands.

Results found in Fig. (9) represent peroxidase banding patterns in China-1 var. were present in $0.2 \mathrm{mg} / 1 \mathrm{TDZ}$ treatment while, each of (Px2, Px5,Px6 andPx7) were present in all treatments and they could be considered as common bands.

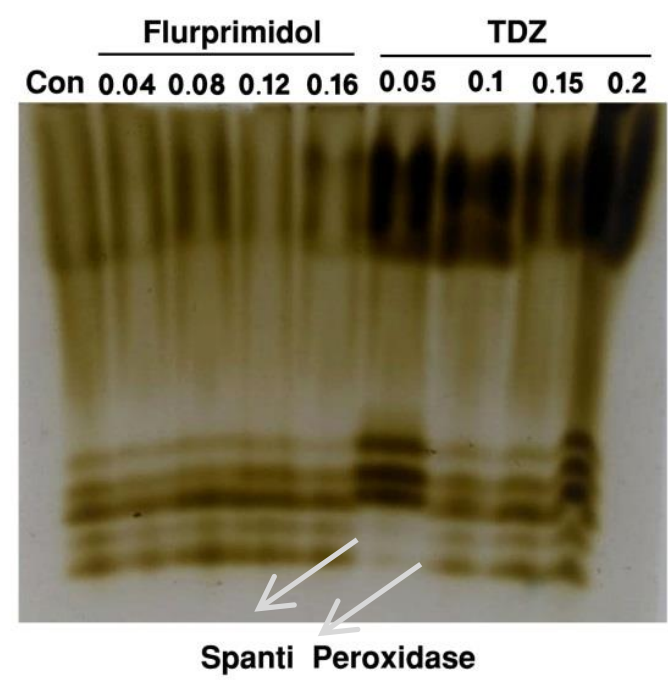

Figure 7. Peroxidase isozyme banding patterns of leaf for stevia cultivar (Spanti) as affected flurprimidol and thidiazuron(mg/l.)as compared with control(con) 


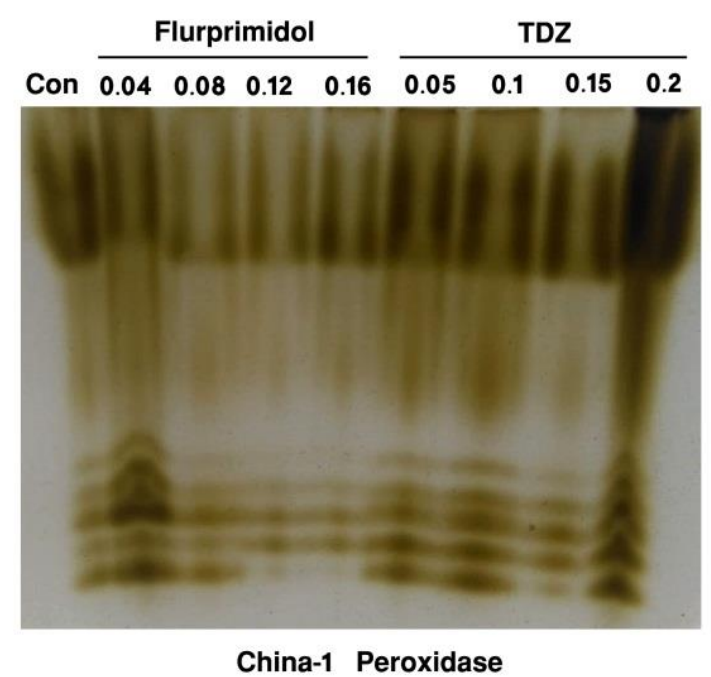

Figure 8. Peroxidase isozyme banding patterns of leaf for stevia cultivar (China-1) as affected flurprimidol and thidiazuron(mg/l.)as compared with control(con)

\section{Polyphenyl oxidase banding patterns:}

Polyphenyl oxidase electrophoretic patterns are illustrated in Fig (9). for Spanti cultivar, there were some differences in density of band compared with the control. Data found that the total of nine Polypheoloxidase bands were present in $0.1,0.15$ and $0.2 \mathrm{mg} / \mathrm{l}$ TDZ treatments. Furthermore, PPO1, PPO5, PPO6, PPO7 and PPO8 bands were present in the both two cultivars and they could be considered as common bands.

According to China-1 cultivar, Fig (10). represent Polypheoloxidase electrophoresis banding patterns, there were some differences in the density of bands compared with the control. Data indicated that, the total of six Polypheoloxidase bands were present in $(0.08$ and $0.15 \mathrm{mg} / \mathrm{l}$ flur.) and $(0.05,0.1$ and0.2mg/l TDZ) treatments and absence in $0.04 \mathrm{mg} / \mathrm{l}$ flur. treatment.

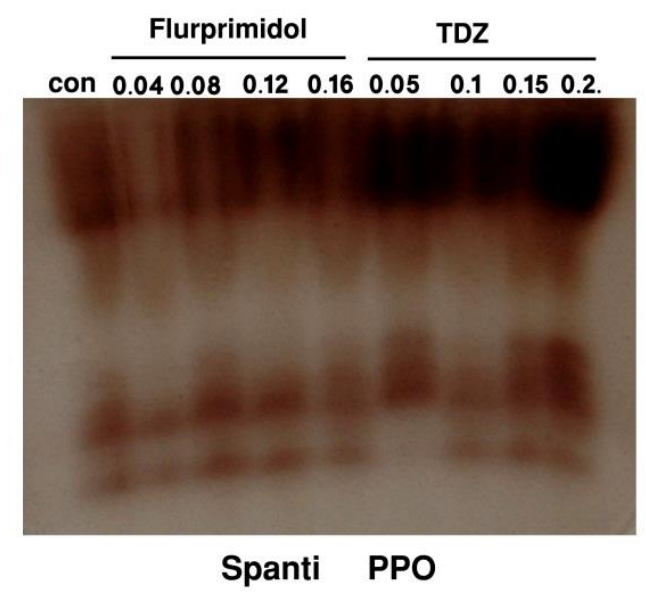

Figure 9. Polypheoloxidase isozyme banding patterns of leaf for stevia cultivar (Spanti) as affected flurprimidol and thidiazuron(mg/l.) as compared with control(con) 


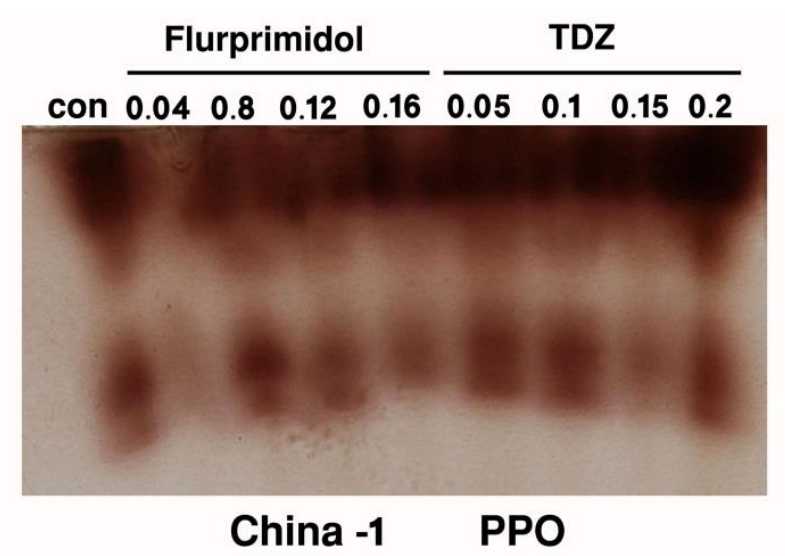

Figure 10. Polypheol oxidase isozyme banding patterns of leaf for stevia cultivar (China-1) as affected flurprimidol and thidiazuron(mg/l.) as compared with control(con)

\section{Conclusion}

It could be concluded that there were significant differences among growth regulator forms and it was found that flurprimidol at $0.16 \mathrm{mgll}$ is a suitable form followed by thidiazuron at $0.2 \mathrm{mg} / \mathrm{l}$ then paclobutrazol at $0.2 \mathrm{mgl}$ on their effects on the growth of different stevia plant tissues and acclimatization. Thidiazuron treatments induced the most of unique bands that explain the greatest number of branches and the highest percentage of callus which produced by using TDZ.

\section{References}

Ahmad, M., McNeil, D. L., \& Fautrier, A. G. (1996). Genetic relationships in Lens species and parentage determination of their interspecific hybrids using RAPD markers. Theor. Applied Genet., 92, 1091-1098. https://doi.org/10.1007/BF00224054

Ahmad, N. M. R., MohdFauzi, R., \& Tsan, F. Y. (2007). Effects of Paclobutrazolon the growth and anatomy of stems and leaves of Syzygium campanulatum. Journal of Tropical Forest Science, 19(2), 86-91.

Ahmad, N. M. R., Tsan, F. Y., \& MohdFauzi, R. (2012). Morphological and physiological response of Syzygium myrtifolium (Roxb.) Walp. to Paclobutrazol. Sains Malaysiana, 41(10), 1187-1192.

Arnon. D. I. (1949). Copper enzymes in isolated chloroplasts. Polyphenol oxidases in Beto .rrlgtrris. Plant Physiol. 24, 1-15. https://doi.org/10.1104/pp.24.1.1

Bai, S., Chaney, W., \& Qi, Y. (2004). Response of cambial and shoot growth in trees treated with paclobutrazol. Journal of Arboriculture, 30(3), 137-145.

Bewley, J. D., \& Black, M. (1994). Seeds Physiology of development and germination Second ed. Plenum Press, New York and London.

Bruinsma, J. (1963). The quantitative analysis of chlorophylls (I and 11 in plant extracts. Photochem. Photobiol, 2(24), 1-249. 
Davis, B. J. (1964). Disc electrophoresis, II Methods and application to human serum proteins. Am-N-Y-Acad.Sci., 121, 404-427.

El Zifzafi, M. M. A. (2003). Physiological studies on Stevia rebaudiana Bertoni through tissue cultures techniques and its suitability for desert regions. Ph.D. Thesis, Dep. Ornam. Hort., Fac. Agri., Cairo Univ., Giza,Egypt.

Fletcher, R. A., Gilley, A., Sankhla, N., \& Davis, T. D. (2000).Triazoles as plant growth regulators and stress protectants. Horticultural Reviews, 24, 55-138.

Francescangeli, N., Marinangeli, P., \& Curvetto, N. (2007). Paclobutrazol for height control of two LiliumL.A. hybrids grown in pots. Spanish Journal of Agricultural Research, 5(3), 425-430. https://doi.org/10.5424/sjar/2007053-266

Goettemoeller, J., \& Ching, A. (1999). Seed germination in Stevia rebaudiana perspective on new crops and new uses. J. Janick (ed.), ASHS press, Alexandria, VA. pp: 510-511.

Gao, J., Hofstra, G., \& Fletcher, R. A. (2011). Anatomical changes induced by triazoles in wheat seedlings. Canadian Journal of Botany, 66(6), 1178-1185. https://doi.org/10.1139/b88-168

Gomez, K. A., \& Gomez, A. A. (1984). Statistical procedures for agricultural research. John Wiley \& Sons Ed., New York, pp680.

Gopi, R., Jaleel, C. A., \& Panneerselvam, R. (2008). Leaf anatomical responses of Amorphophalluscampanulatusto triazoles fungicides. EurAsian Journal of BioSciences 2, 46-52.

Graham, R. C., Lundholm, U., \& Karnovsky, M. J. (1964). Cytochemical demonstration of peroxidase activity with 3-amino-g-ethylcarbazole. J. Histochem. Cytochem. 13, 150-152. https://doi.org/10.1177/13.2.150

Hajihashemi, S., \& Geuns, J. M. C. (2017). Steviol glycosides correlation to genes transcription revealed in gibberellin and paclobutrazol-treated Stevia rebaudiana. J. Plant Biochem. Biotechnol. 26(4), 387-394. https://doi.org/10.1007/s13562-017-0399-5

Ibrahim, I. A., Nasr, M. I., Mohammed, B. R., \& EL-Zifzafi, M. M. (2008). Plant growth regulators affecting in vitro cultivation of Stevia rebaudiana. Sugar Tech., 3(10), 248-253. https://doi.org/10.1007/s12355-008-0044-7

Ilczuk1, A., Winkelmann, T., Richartz, S., Witomska, M., \& Serek, M. (2005). In vitro propagation of Hippeastrum 3 chmielii Chm. - influence of flurprimidol and the culture in solid or liquid medium and in temporary immersion systems. Plant Cell, Tissue and Organ Culture, 83, 339-346.

Jaleel, C. A., Gopi, R., Azooz, M. M., \& Panneerselvam, R. (2009). Leaf anatomical modifications in Catharanthus roseusas affected by plant growth promoters and retardants. Global Journal of Molecular Sciences, 4(1), 1-5.

Jenks, M. A., Andersen, L., Teusink, R. S., \& Williams, M. H. (2001). Leaf cuticular waxes of 
potted rose cultivars as affected by plant development, drought and paclobutrazol treatments. Plant Physiology, 112, 62-70. https://doi.org/10.1034/j.1399-3054.2001.1120109.x

Jonathan, F. W., \& Weeden. N. F. (1990). Visualization and interpretation of plant isozymes. Isozymes in Plant Biology. D.E. Soltis and P.S. Soltis (eds). London Chpman and Hall, pp.5-45.

Kozak, D. (2006). The effect of growth retardants applied in vitro on the acclimatization and growth of Tibouchinaur villeanacogn. in vivo.Acta Sci. Pol., Hortorum Cultus, 5(1), 65-70.

Koornneef, M., Bentsink, L., \& Hilhorst, H. (2002). Seed dormancy and germination. Curr. Opin. Plant Biol. (5), 33-36. https://doi.org/10.1016/S1369-5266 (01) 00219-9

Krug, B. A., Whipker, B. E., McCall, I., \& Dole, J. M. (2006). Narcissus response to plant $\begin{array}{llll}\text { growth } & \text { regulators. } & \text { HortTechnology, } & 16,\end{array}$ https://doi.org/10.21273/HORTTECH.16.1.0129

Latimer, J., \& Whipker, B. (2007). Using piccolo with herbaceous perennials. Edited by Fine America, Inc.

Laemmli, U. K. (1970). Cleavage of structural proteins during the assembly of the head of bacteriophage T4. Nature, 227, 680-685. https://doi.org/10.1038/227680a0

Mahdy E. M., Soliman, S. S., Fayed, A. H., \& Hassan, N. A. (2012). Morphological and cytogenetical characterization for eight Egyptian accessions of jew's mallow. Zagazig J. Agric. Res. 39(3), 409-418.

Mansuroglu, S., Karaguzel, O., Ortacesme, V., \& Sayan, M. S. (2009). Effect of paclobutrazolon flowering, leaf and flower colour of Consolida orientalis. Pakistan Journal of Botany, 41(5), 2323-2332.

Massoud, M. I. (2001). Chemical and technological studies on natural sweeteners from Steviaplant. Ph.D. Thesis, Food Sci. Tech. Depart., Fac. Agric., Alexandria Uni., Egypt.

Murashige, T., \& Skoog, F. (1962). A revised medium of rapid growth and bioassay with tobacco tissue culture. Plant Physiol. 15, 573-497.

Nassar, M. A., \& El-Sahhar K. F. (1998). Botanical Preparations and Microscopy (Microtechnique). Academic Bookshop, Dokki, Giza, Egypt, p 219.

Oddone, B. (1997). How to grow stevia. Technical manual. Guarani Botanicals, Pawtucket, CT. http://www.scribd.com/doc/6390515/Advances-in-Agronomy-Volume-89.

Ojeda, F. S., Hoc, P. S., \& Garcia, M. T. A. (2013). Morphology of seeds and seedlings of four species of VignaSavi (Leguminosae, Phaseolinae). Acta Bot. Bras., 27(3), 483-489. https://doi.org/10.1590/S010233062013000300004

Rademacher, E. (2000). Growth retardants: Effects on gibberellin biosynthesis and other metabolic pathway. Annual Review of Plant Physiology and Plant Molecular Biology, 51, 501-531. https://doi.org/10.1146/annurev.arplant.51.1.501 
Salachna, P., \& Zawadzińska. A. (2013). The effects of flurprimidol concentrations and application methods on Ornithogalum saundersiae Bak. grown as a pot plant. 8(49), $6625-6628$

Sapna, S., Kondalkar, A., Tailang, M., \& Pathak, A. K. (2008). PHCOG MAG: Research Article Pharmacognostic and Phytochemical Investigation of Stevia rebaudiana. Phcog Mag. 4, Issue 13 (Suppl), PHCOG MAG. An official Publication of Phcog. Net.

Sebastian, B., Alberto, G., Emilio, A. C., Jose, A. F., \& Juan, A. F. (2002). Growth, development and color response of potted Dianthus caryophylluscv. Mondrian to paclobutrazoltreatment. Scientia Horticulturae, 17(67), 1-7.

Selvakumar, G., \& Kumari, R. U. (2015). Phenotypic expression in inter subspecies crosses of cowpea (Vignaun guiculata (L.) Walp.) and Yard Long Bean (Vignaun guiculata (L.) Walp. spp. sesquipedalis). Jour. Pl. Sci. Res., 31(1), 101-108.

Slack, K. V., Avekett, R. C., Giieenson, P. E., \& Lipscomb, R. G. (1973). Methods for collection and analysis of aquatic biological and mic .obiological samples. U.S. Geol. Surv.. Tech. Water Resour. Invest. Book.

Soejarto, D. D., Compadre, C. M., Medon, P. J., Kamath, S. K., \& Kinghorn, A. D. (1983). Potential sweetening agents of plant origin. Econ. Bot., 37(1), 71-79. https://doi.org/10.1007/BF02859308

Tamura, Y., Nakamura, S., Fukui, H., \& Tabata, M. (1984). Clonal propagation of Stevia rebaudiana Bertoni by stem-tip culture. PlantCell Reports. 3(5), 183-185. https://doi.org/10.1007/BF00270195

Tankesley, S. D., \& Rick, C. M. (1980). Genetic of estrases in species of Lycpersicon. Theor. Appl.Genet.56:209-219. https://doi.org/10.1007/BF00295451

Taware, A. S., Harke, S. N., Mukadam, D. S., Chavan, A. M., \& Taware, S. D. (2010). Effect of differentextracts of callus and plantlets of Stevia rebaudiana (Bertoni) on seed germination of some agricultural crops. Afr. J. Biotechnol., (9), 6675-6683.

Tekalign, T., Hammes, P. S., \& Robbertse, J. (2005). Paclobutrazol-induced leaf, stem, and root anatomical modifications in potato. Hort Science, 40(5), 1343-1346.

Yeshitela, T., Robbertse, P. J., \& Stassen, P. J. C. (2004). Paclobutrazol suppressed vegetative growth and improved yield as well as fruit quality of 'Tommy Atkins' mango (Mangifera indica) in Ethiopia. New Zealand Journal of Crop and Horticultural Science, 32, 281-293. https://doi.org/10.1080/01140671.2004.9514307

\section{Copyright Disclaimer}

Copyright for this article is retained by the author(s), with first publication rights granted to the journal.

This is an open-access article distributed under the terms and conditions of the Creative Commons Attribution license (http://creativecommons.org/licenses/by/4.0/). 